\title{
Fast HPLC Analysis of Omeprazole, 5-Hydroxyomeprazole and Omeprazole Sulfone in Liquid Culture Medium using a Monolithic Column for Application in Biotransformation Studies with Fungi
}

\author{
Keyller B. Borges, ${ }^{a}$ Rosa Durán-Patrón, ${ }^{b}$ Antonio José M. Sánchez, ${ }^{b}$ Mônica T. Pupo, ${ }^{c}$ \\ Pierina S. Bonato ${ }^{*, a}$ and Isidro G. Collado $*, b$ \\ ${ }^{a}$ Departamento de Física e Química and ${ }^{c}$ Departamento de Ciências Farmacêuticas, \\ Faculdade de Ciências Farmacêuticas de Ribeirão Preto, Universidade de São Paulo, \\ Av. do café, s/n, 14040-903 Ribeirão Preto-SP, Brazil \\ ${ }^{b}$ Departamento de Química Orgánica, Facultad de Ciencias, Universidad de Cádiz, \\ Poligono Rio San Pedro s/n, 11510 Puerto Real, Cádiz, Spain
}

\begin{abstract}
Um método rápido por cromatografia líquida foi desenvolvido para a determinação simultânea de omeprazol (OMZ), 5-hidroxiomeprazol (5-HOMZ) e omeprazol sulfona (OMZ SUL) em meio de cultura líquido, para aplicação em estudos de biotransformação empregando fungos fitopatogênicos e endofíticos. A separação foi realizada empregando uma coluna monolítica Chromolith Fast gradient RP 18 com a fase móvel constituída por ácido trifluoroacético (TFA) 0,15\% (v/v) em água (solvente A) e TFA 0,15\% (v/v) em acetonitrila (solvente B). Foi empregado um gradiente linear de 5 a $90 \%$ de $\mathrm{B}$ em 1 minuto, vazão de $1,0 \mathrm{~mL} \mathrm{~min}^{-1}$, temperatura de $30{ }^{\circ} \mathrm{C}$ e detecção em $220 \mathrm{~nm}$. A extração líquido-líquido foi empregada na preparação das amostras, com recuperações na faixa de $62,3-76,6 \%$ para todos os analitos. O método foi linear na faixa de $0,2-10,0 \mu \mathrm{g} \mathrm{mL} \mathrm{m}^{-1}$ $(r \geq 0,995)$. Os valores de precisão e exatidão intra- e inter-dias (coeficiente de variação e erro relativo) foram inferiores a $15 \%$ para todos os analitos. O método validado foi utilizado para avaliar a biotransformação do OMZ em seus principais metabólitos humanos pelos fungos selecionados. Em geral, os fungos fitopatogênicos foram mais eficientes para biotransformar o OMZ. A reação de sulfonação foi mais prevalente em todos os fungos estudados.
\end{abstract}

A fast liquid chromatography method was developed and validated for the simultaneous determination of omeprazole (OMZ), 5-hydroxyomeprazole (5-HOMZ) and omeprazole sulphone (OMZ SUL) in liquid culture medium for application in biotransformation studies employing phytopathogenic and endophytic fungi. The separation was achieved using a monolithic Chromolith Fast gradient RP 18 endcapped column, using a mobile phase consisting of $0.15 \%(\mathrm{v} / \mathrm{v})$ trifluoroacetid acid (TFA) in water (solvent A) and $0.15 \%$ (v/v) TFA in acetonitrile (solvent B), under linear gradient of 5 to $90 \%$ of $\mathrm{B}$ in $1 \mathrm{~min}$, flow rate of $1.0 \mathrm{~mL} \mathrm{~min}{ }^{-1}$, temperature at $30{ }^{\circ} \mathrm{C}$ and detection at $220 \mathrm{~nm}$. Sample preparation was performed by liquid-liquid extraction, with recoveries in the range of 62.3 to $76.6 \%$ for all analytes. The method was linear in the range of 0.2 to $10.0 \mu \mathrm{g} \mathrm{mL}^{-1}(r \geq 0.995)$. The values for intra- and inter-day precision (\% coefficient of variation) and accuracy (\% relative error) were $<15 \%$ for all analytes. The validated method was used to evaluate OMZ biotransformation to their mammalian metabolites by selected fungi. In general, the phytopathogenic fungi studied were more efficient to biotransform OMZ. The sulfonation reaction was more prevalent for all studied fungi.

Keywords: fast liquid chromatography, monolithic column, omeprazole, 5-hydroxyomeprazole, omeprazole sulphone, biotransformation

*e-mail: psbonato@fcfrp.usp.br; isidro.gonzalez@uca.es 


\section{Introduction}

Omeprazole (OMZ) is a proton pump inhibitor used in the treatment of dyspepsia, peptic ulcer disease, gastroesophageal reflux disease and Zollinger-Ellison syndrome. Its mechanism of action is selective by an inhibition of the hydrogen-potassium adenosine triphosphatase enzyme $\left(\mathrm{H}^{+} / \mathrm{K}^{+}\right.$ATPase $)$of the parietal cells, leading to a reduction of the gastric acid secretion. ${ }^{1-3}$ The main metabolites of OMZ observed in human plasma are 5-hydroxyomeprazole (5-HOMZ) and omeprazole sulphone (OMZ SUL) (Figure 1). It is well established that CYP2C19 is the major enzyme involved in the formation of 5-HOMZ whereas CYP3A4 is mainly involved in the production of OMZ SUL. ${ }^{4}$

Several analytical methods for the determination of OMZ alone or with its metabolites in biological samples, bulk material or pharmaceutical formulations, have been reported in the literature. Older methods were extensively reviewed by Bosch et al..$^{5}$ For the analysis of OMZ and its metabolites in biological matrices, HPLC has been the technique most employed..$^{5-13}$ Although these methods are quite suitable for the analysis of OMZ and its metabolites in biological matrices, all of them are characterized by relatively long analysis time. Recently, we studied the highspeed analysis of OMZ in pharmaceutical formulations using a monolithic column. ${ }^{14}$ Based on the good results obtained, we decided to use this column to develop a method for the simultaneous determination of OMZ, 5-HOMZ and OMZ SUL in liquid culture medium to study the biotransformation of OMZ by fungi.

The evaluation of the efficacy and safety of a drug requires large amounts of metabolites to be used in the development of analytical methods, in pharmacokinetic, pharmacodynamic and toxicologic studies and others.
These metabolites could be obtained by using synthetic routes which posses disadvantages such as relatively complicated synthesis, multi-step process, large amount of halogen-containing wastes and the use of some very toxic reactants. An alternative procedure is the use of microbial models ${ }^{15-17}$ as some microorganisms can metabolize drugs in a similar manner to mammals. Fungi have been extensively used for biotransformation studies since they provide an efficient and environmentally friendly means for achieving large-scale metabolite production of a range of drugs. ${ }^{18-20}$ They can generate the same metabolites produced by humans and other mammals as well as metabolites unique to their genus.

In this study, OMZ was selected as a model drug to evaluate the effectiveness of phytopathogenic and endophytic fungi to perform sulfonation and hydroxylation reactions. The term endophytic fungi have been employed to describe those fungi that can be detected at a particular moment within apparently healthy plant host tissue. Endophytes invade the tissue of living plants causing unapparent and asymptomatic infections. ${ }^{21,22}$ Endophytic fungi have been employed in biotransformation studies of different drugs. ${ }^{23-29}$ Phytopathogenic fungi can cause disease by colonizing parts of animals and plants internally or externally. Phytopathogenic fungi may also exhibit long latency periods, that is, symptom-free occupation of host tissue. ${ }^{30}$ Some phytopathogenic fungi have been also employed in biotransformation process. ${ }^{31,32}$

\section{Experimental}

\section{Chemicals and reagents}

OMZ and OMZ SUL were kindly supplied by AstraZeneca (Mölndal, Sweden). 5-HOMZ was obtained

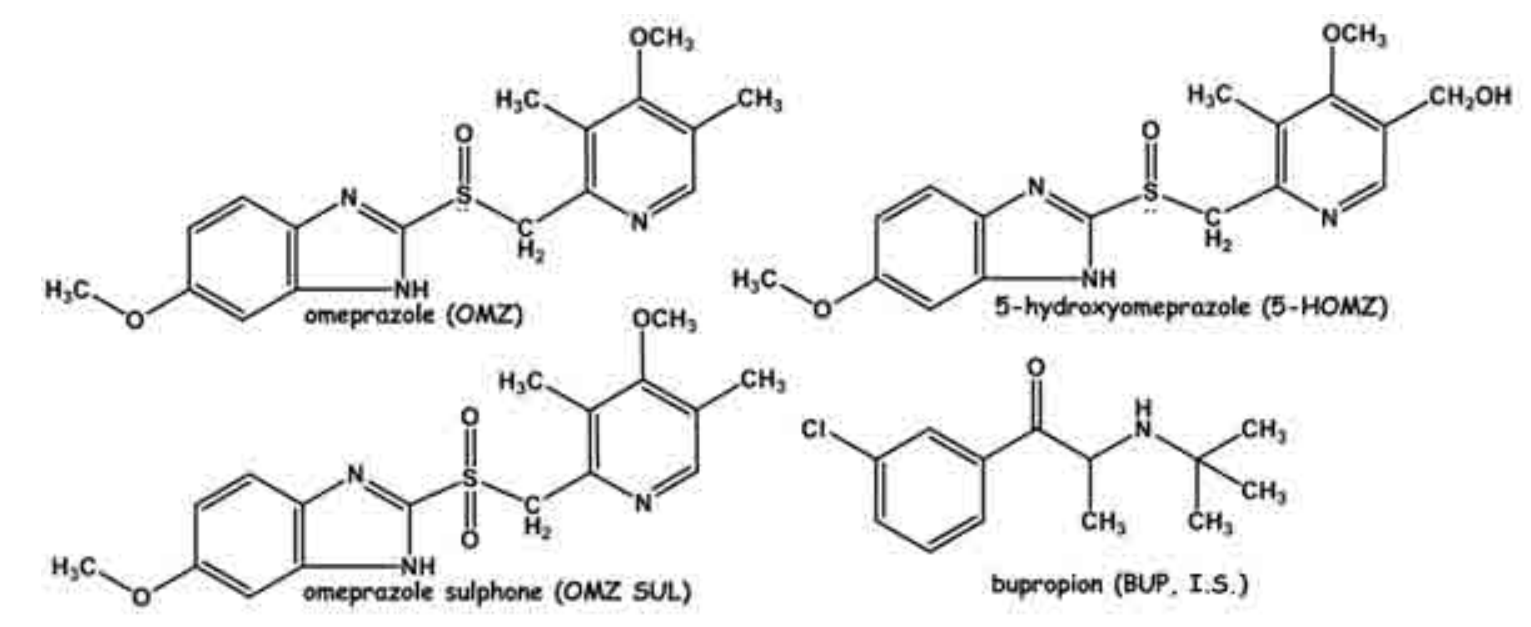

Figure 1. Chemical structures of omeprazole (OMZ), 5-hydroxyomeprazole (5-HOMZ), omeprazole sulphone (OMZ SUL) and bupropion (BUP, I.S.). 
from Toronto Research Chemicals Inc. (North York, ON, Canada). Bupropion (internal standard, IS) was kindly supplied by Glaxo Smith Kline (Rio de Janeiro, RJ, Brazil). All reagents used in the biotransformation reactions were analytical grade in the highest purity available. All aqueous solutions were prepared with water distilled and purified using a Millipore Milli-Q Plus system (Bedford, MA, USA). HPLC-grade methanol and acetonitrile were obtained from Merck (Darmstadt, Germany). Trifluoroacetic acid, ethyl acetate and ethanol (p.a. grade) were purchased from PRS (Barcelona, Spain). tert-Butyl ethyl ether (p.a.) was obtained from Sigma Aldrich (Dorset, UK).

\section{Instrumentation and analytical conditions}

Experiments were performed on a LaChromUltra Hitachi High Technologies chromatographic system (Pleasanton, CA, USA) consisting of a double L-2160 U pump, an L-2455 U Diode Array Detector, an organizer, an L-2200 U auto sampler, and an L-2300 column oven. The EZChrom Elite software (Agilent Technologies, Pleasanton, CA, USA) was used to control the LC system and for data acquisition. Separation was performed on a Chromolith Fast gradient RP 18 endcapped column (Merck, $50 \times 2.0 \mathrm{~mm}$ ). The separation was accomplished with a mobile phase consisting of $0.15 \%(\mathrm{v} / \mathrm{v})$ trifluoroacetic acid (TFA) in water (solvent $\mathrm{A}$ ) and $0.15 \%(\mathrm{v} / \mathrm{v})$ TFA in acetonitrile (ACN) (solvent $\mathrm{B}$ ), using a linear gradient of 5 to $90 \%$ of B in $1 \mathrm{~min}$. Diode array detection was from 190 to $600 \mathrm{~nm}$ (UV at $220 \mathrm{~nm}$ for data analysis). All chromatographic procedures were conducted at $30{ }^{\circ} \mathrm{C}$. A flow rate of $1.0 \mathrm{~mL} \mathrm{~min}^{-1}$ was used. The injection volume was $5 \mu \mathrm{L}$ for standards and samples.

\section{Preparation of standards}

Stock standard solutions of OMZ, 5-HOMZ and OMZ SUL were prepared by dissolution of the drugs in methanol to obtain a concentration of $2000 \mu \mathrm{g} \mathrm{mL}^{-1}$. From these stock solutions, working standards were prepared by dilutions to obtain the concentrations of $16,20,40,80,240,480$ and $800 \mu \mathrm{g} \mathrm{mL}^{-1}$. The concentration of internal standard bupropion (BUP) was $100 \mu \mathrm{g} \mathrm{mL}^{-1}$. The stock solutions and the working standards were stored at $-20^{\circ} \mathrm{C}$ in well-closed and light resistant containers.

\section{Sample preparation}

The extraction of $1 \mathrm{~mL}$ aliquots of the liquid culture medium spiked with $25 \mu \mathrm{L}$ of bupropion (IS, $100 \mu \mathrm{g} \mathrm{mL}^{-1}$ ) was performed with $4 \mathrm{~mL}$ of a mixture of ethyl acetate: $t$-butyl methyl ether $(9: 1, \mathrm{v} / \mathrm{v})$, after alkalinization with $100 \mu \mathrm{L}$ of $2 \mathrm{~mol} \mathrm{~L}^{-1} \mathrm{NaOH}$ solution. Drugs were extracted into a vortex shaker for $3 \mathrm{~min}$. After centrifugation at $1800 \times \mathrm{g}$ for $3 \mathrm{~min}$, the organic phase $(3 \mathrm{~mL})$ was separated and the solvent was evaporated under nitrogen. The residue was dissolved in $400 \mu \mathrm{L}$ of mobile phase and placed in the automatic injector for injection of $5 \mu \mathrm{L}$.

\section{Method validation}

The selectivity of the method was evaluated by analyzing sterile medium and fungal mycelium under the conditions previously established to verify possible interferents of reagents and secondary metabolites of each studied fungi.

The recovery study was performed extracting $1 \mathrm{~mL}$ liquid culture medium spiked with standard solutions of OMZ, 5-HOMZ and OMZ SUL to obtain the concentrations of 1.0, 3.0 and $6.0 \mu \mathrm{gL}^{-1}(\mathrm{n}=3)$. Another set of samples was prepared extracting $1 \mathrm{~mL}$ aliquots of liquid culture medium and then spiking the extract with the same amount of OMZ, 5-HOMZ and OMZ SUL. The recovery was determined by comparing the areas obtained before and after extraction and was expressed as percentage of the amount extracted.

Calibration curves were prepared by analyzing aliquots of $1 \mathrm{~mL}$ of liquid culture medium spiked with OMZ and its metabolites to achieve the final concentrations of 0.20 , $0.25,0.50,1.0,3.0,6.0$ and $10.0 \mu \mathrm{g} \mathrm{mL}^{-1}$. Bupropion (IS) was added to all samples. The tests were performed in triplicates for each concentration.

The limits of quantification (LOQ), defined as the lowest concentration that could be determined with accuracy and precision below $20 \%,{ }^{33}$ were determined by analyzing samples of $1 \mathrm{~mL}$ of liquid culture medium $(\mathrm{n}=6)$ spiked with 5-HOMZ, OMZ and OMZ SUL to obtain a concentration of $0.20 \mu \mathrm{g} \mathrm{mL}^{-1}$.

Within-day precision and accuracy were achieved by six replicates analysis $(n=6)$ of liquid culture medium samples spiked with standard solutions of the drug and metabolites at low, medium and high concentration levels (1.0, 3.0 and $\left.6.0 \mu \mathrm{g} \mathrm{mL}^{-1}\right)$. Between-day precision and accuracy were conducted during routine operation of the system over a period of three consecutive working days. The overall precision of the method was expressed as percentage of coefficient of variation $(\mathrm{CV}, \%)$, while the accuracy was expressed as percentage of relative error (E, \%).

The stability test of 5-HOMZ, OMZ and OMZ SUL was evaluated by studying the influence of freeze $\left(-20^{\circ} \mathrm{C}\right)$ and thaw $\left(22 \pm 2^{\circ} \mathrm{C}\right)$ cycles, short-term room temperature ( $8 \mathrm{~h}$ on the auto sampler) and $48 \mathrm{~h}$ stored at $-20^{\circ} \mathrm{C}$. Six 
replicates $(n=6)$ of spiked liquid culture medium at the low $\left(1.0 \mu \mathrm{g} \mathrm{mL}^{-1}\right)$ and high concentration $\left(6.0 \mu \mathrm{g} \mathrm{mL}^{-1}\right)$ were prepared to perform the stability test. The peak areas obtained from the stability tests were compared to the peak areas obtained with freshly prepared samples. One-way ANOVA test was applied, with the level of significance set at $p \leq 0.05$.

\section{Endophytic and pathogenic fungi isolation and maintenance}

The phytopatogenic fungi selected were Botrytis cinerea 2100 (BC), Colletotrichum acutatum 348489 (CA), Colletotrichum gloeosporioides 20122 (CG) and Eutypa lata (EL). The phytopatogenic fungi employed in this work were obtained from the "Colección Española de Cultivos Tipo" (CECT). The selected strains of endophytic fungi were Glomerella cingulata (VA1) and Guignardia mangiferae (VA15) isolated from V. arenaria, Penicillium crustosum (VR4), Chaetomium globosum (VR10) and Aspergillus fumigatus (VR12) isolated from V. robusta. The strains have been deposited in the Academic Laboratory of Chemistry of Microorganisms, Faculty of Pharmaceutical Sciences of Ribeirão Preto (University de São Paulo, Ribeirão Preto, Brazil). The fungi have been maintained as conidial stock suspensions or agar plugs in $80 \%$ glycerol at $-70{ }^{\circ} \mathrm{C}$.

Biotransformation study of OMZ employing endophytic and phytopathogenic fungi

Fungi were grown at $25^{\circ} \mathrm{C}$ for 7 days in $9.0 \mathrm{~cm}$ diameter Petri dishes containing potato dextrose agar. Three uniform discs of $0.9 \mathrm{~cm}$ diameter of each fungus studied were transferred aseptically to $50 \mathrm{~mL}$ Falcon tubes containing $10 \mathrm{~mL}$ of pre-fermentative medium $(10.0 \mathrm{~g}$ malt extract, $10.0 \mathrm{~g}$ dextrose, $5.0 \mathrm{~g}$ triptone and $3.0 \mathrm{~g}$ yeast extract and distilled water to $1 \mathrm{~L}$. The $\mathrm{pH}$ was adjusted to $6.2 \pm 0.2$ with a solution of $0.5 \mathrm{~mol} \mathrm{~L}^{-1} \mathrm{HCl}$ ) for the growth of the microorganisms. After five days, the mycelium was completely transferred to $500 \mathrm{~mL}$ Erlenmeyer flask containing $200 \mathrm{~mL}$ of modified buffered Czapek Dox medium ( $2.0 \mathrm{~g}$ glucose, $0.2 \mathrm{~g}$ yeast, $0.4 \mathrm{~g} \mathrm{NaNO}_{3}, 0.1 \mathrm{~g}$ $\mathrm{MgSO}_{4} \cdot 7 \mathrm{H}_{2} \mathrm{O}, 0.002 \mathrm{~g} \mathrm{FeSO}_{4} \cdot 7 \mathrm{H}_{2} \mathrm{O}, 13.9 \mathrm{~g} \mathrm{~K}_{2} \mathrm{HPO}_{4}, 10.9 \mathrm{~g}$ $\mathrm{KH}_{2} \mathrm{PO}_{4}$, and distilled water to $100 \mathrm{~mL}$, $\mathrm{pH}$ adjusted to 7.0). Solutions of OMZ ( $2 \mathrm{mg}$ ) in ethanol were added to each of studied culture. The cultures were incubated with orbital shaking $(120 \mathrm{rpm})$ at $25^{\circ} \mathrm{C}$ for $24 \mathrm{~h}$ in the darkness. Aliquots were filtered through a Millipore membrane filter $(0.45 \mu \mathrm{m}$, Millipore, Bedford, MA, USA) and then $1 \mathrm{~mL}$ of filtrate was submitted to extraction procedure and analyzed by the method described in this paper. Control tubes consisted of culture broth without $\mathrm{OMZ}$ and fungi, sterile medium with OMZ without fungi and fungal mycelium of each studied endophytic and phytopathogenic fungi.

\section{Results and Discussions}

\section{Method development and validation}

The demand for new analytical technologies able to promote fast or ultra fast separation using short columns packed with small particles (i.e. sub-2 $\mu \mathrm{m})^{34-39}$ resistant to high pressure or high temperature mobile phase $e^{40-45}$ has grown in the last years. In addition, a possible tool to convert a standard LC method into a fast LC method is the use of monolithic silica columns. Due to the high permeability of monolithic columns ${ }^{46-49}$ provided by the bimodal pore structure, high flow rates can be used with acceptable backpressure..$^{50,51}$

The analysis of OMZ in enteric coated pellets has already been studied by our group. ${ }^{14}$ Some modifications on the method were performed to achieve the simultaneous separation of OMZ, 5-HOMZ and OMZ SUL. Although the method has used a fast gradient employing a flow rate of $1 \mathrm{~mL} \mathrm{~min}^{-1}$, no re-equilibrium was necessary to perform the next analysis. The best conditions were achieved providing satisfactory resolution for all analytes $(R s>2.5)$ in only $1 \mathrm{~min}$. The optimized chromatographic conditions are described on Figure 2 that also shows typical chromatogram of OMZ, 5-HOMZ, OMZ SUL and BUP (IS). Under these conditions, 5-HOMZ eluted around $0.70 \mathrm{~min}$, OMZ with $0.74 \mathrm{~min}$, OMZ SUL with $0.79 \mathrm{~min}$. Some compounds were evaluated as internal standard and among them bupropion (BUP) presented better results (0.91 $\mathrm{min})$.

Figure 3 shows the chromatograms obtained for the analysis of blank liquid culture medium of the phytopathogenic fungi (Figure 3a) and endophytic fungi (Figure 3b) after $24 \mathrm{~h}$ of incubation. The evaluation of method selectivity showed that only the fungus Penicillium crustosum (VR4) presented secondary metabolites coeluting with the analytes. A secondary metabolite presented a peak at the same retention time of BUP. Therefore, this microorganism was removed from the study.

Some solvents or mixture of solvents at different compositions were evaluated to extract 5-HOMZ, OMZ, and OMZ SUL from liquid culture medium employing liquid-liquid extraction (LLE) and the selected one was ethyl acetate: tert-butyl methyl ether (9: 1, v/v). Recoveries of 5-HOMZ, OMZ, and OMZ SUL were approximately 65,75 and $67 \%$, respectively. The percentages of CV for all analytes were lower than $15 \%$. Results are summarized in Table 1. 


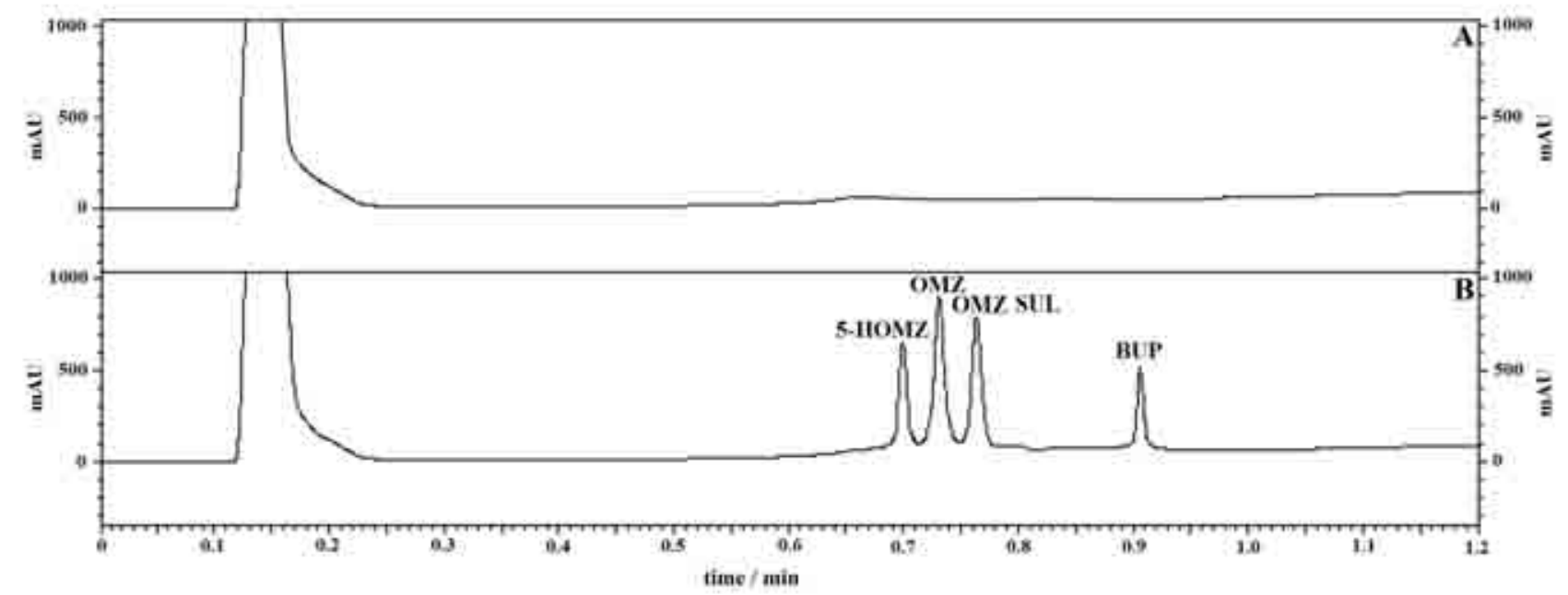

Figure 2. Typical chromatogram showing the (A) Blank of liquid culture medium and (B) the separation of 5-HOMZ, OMZ, OMZ SUL and BUP. Chromatographic conditions: Chromolith Fast gradient RP 18 endcapped column (Merck, $50 \times 2.0 \mathrm{~mm}$ id); linear gradient of $0.15 \%$ (v/v) trifluoroacetid acid (TFA) in water (solvent A) and $0.15 \%$ (v/v) TFA acetonitrile (ACN) (solvent B), 5 to $90 \%$ of B in 1 min; column temperature of $30{ }^{\circ} \mathrm{C}$; flow rate of $1.0 \mathrm{~mL} \mathrm{~min}^{-1}$ and DAD detection from 190 to $600 \mathrm{~nm}$ (UV at $220 \mathrm{~nm}$ for data analysis). The injection volume was $5 \mu \mathrm{L}$ for standards and samples.

Response ratio of peak areas between the corresponding compound and the internal standard versus theoretical concentration was fitted by a least-square linear regression. The calibration curves were linear over the concentration range of $0.2-10 \mu \mathrm{g} \mathrm{mL}^{-1}$. The correlation coefficients for all analytes were $(r) \geq 0.99$ (Table 2). The limits of quantification of the validated method are also presented in Table 2. The coefficients of variation and relative errors were lower than $15 \%$.

The results for within-day and between-day precision and accuracy at concentration levels of 1.0, 3.0 and $6.0 \mu \mathrm{g}$ $\mathrm{mL}^{-1}$ for 5-HOMZ, OMZ, and OMZ SUL are summarized in Table 3. These results show that the method is precise and accurate within the desired range.

To perform the stability test, spiked liquid culture medium were prepared in six replicates $(n=6)$. The samples at the low $\left(1.0 \mu \mathrm{g} \mathrm{mL}^{-1}\right)$ and high concentration $\left(6.0 \mu \mathrm{g} \mathrm{mL}^{-1}\right)$ were analyzed freshly, after $8 \mathrm{~h}$ on the auto sampler, after freeze/thaw cycles, or after $48 \mathrm{~h}$ frozen at $-20^{\circ} \mathrm{C}$. Stability data are summarized in Table 4 . As can be seen from the values, there were no statistically significant loss since all $p$-values were $>0.05$ (one-way ANOVA, NS).

OMZ stability studies reported in the literature have revealed that it is acid labile and sensitive to light and heat, suggesting the possible formation of degradation products. ${ }^{53}$ Therefore, the biotransformation reaction of OMZ was conducted in darkness and in buffered medium (pH 7.0).

The stability of OMZ under the biotransformation conditions was evaluated by the analysis of a control tube consisting of sterile medium with OMZ. No degradation of OMZ could be observed up to $24 \mathrm{~h}$ incubation. Studies with time over $24 \mathrm{~h}$ showed that there was significant degradation of the substrate OMZ.

Table 1. Extraction yield data for 5-hydroxyomeprazole, omeprazole and omeprazole sulphone in Czapek Dox medium

\begin{tabular}{|c|c|c|c|}
\hline Drug & 5-Hydroxyomeprazole & Omeprazole & Omeprazole Sulfone \\
\hline \multicolumn{4}{|l|}{$1 \mu \mathrm{g} \mathrm{mL}^{-1}$} \\
\hline Recovery (mean, \%) & 62.3 & 75.3 & 67.9 \\
\hline $\mathrm{CV}(\%)^{\mathrm{b}}$ & 5.1 & 2.7 & 4.0 \\
\hline \multicolumn{4}{|l|}{$3 \mu \mathrm{g} \mathrm{mL}^{-1}$} \\
\hline Recovery (mean, $\%)^{\mathrm{a}}$ & 62.5 & 73.9 & 65.9 \\
\hline $\mathrm{CV}(\%)^{\mathrm{b}}$ & 6.0 & 3.5 & 5.9 \\
\hline \multicolumn{4}{|l|}{$6 \mu \mathrm{g} \mathrm{mL}^{-1}$} \\
\hline Recovery (mean, \%) & 66.3 & 76.6 & 66.1 \\
\hline $\mathrm{CV}(\%)^{\mathrm{b}}$ & 1.8 & 5.4 & 5.2 \\
\hline
\end{tabular}

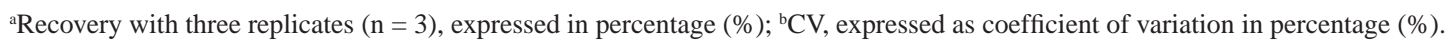



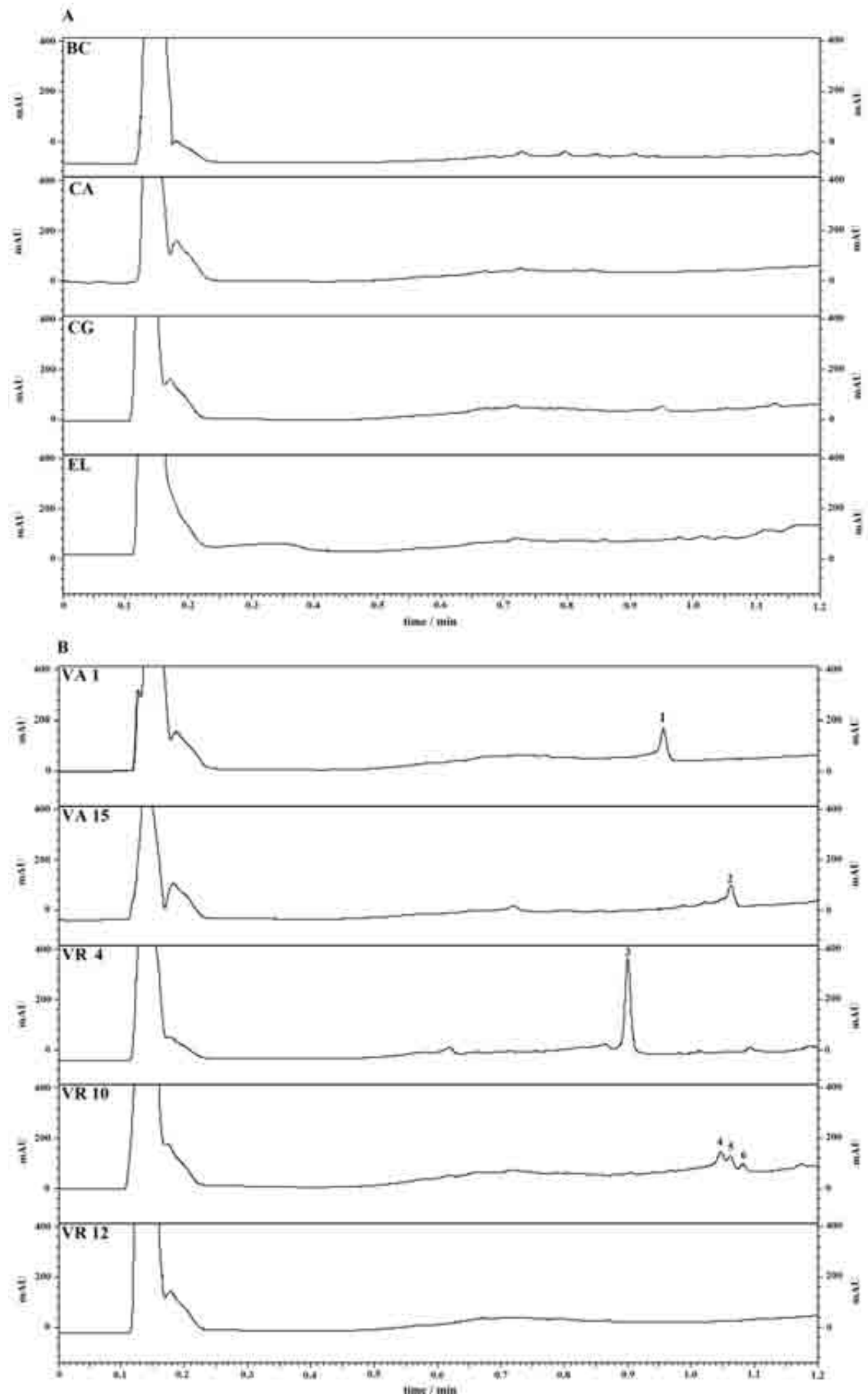

Figure 3. A) Chromatograms referring to the analysis of liquid culture medium of the phytopatogenic fungi: Botrytis cinerea (BC), Colletotrichum acutatum (CA), Colletotrichum gloeosporioides (CG) and Eutypa lata (EL); B) Chromatograms referring to the analysis of liquid culture medium of the endophytic fungi: Glomerella cingulata (VA1, 1: unknown secondary metabolite), Guignardia mangiferae (VA15, 2: unknown secondary metabolite), Penicillium crustosum (VR4, 3: unknown secondary metabolite), Chaetomium globosum (VR10, 4, 5 and 6: unknown secondary metabolites) and Aspergillus fumigatus (VR12). The conditions are the same as in Figure 2. 
Table 2. Linearity and limit of quantification of the method for the analysis of 5-hydroxyomeprazole, omeprazole and omeprazole sulphone in Czapek Dox medium

\begin{tabular}{lcc}
\hline Drug & 5-Hydroxyomeprazole & Omeprazole \\
\hline Linear equation & & 0.5660 \\
$\quad$ Slope & 0.4852 & 0.1439 \\
Intercept & 0.1113 & 0.9959 \\
Correlation coefficient $(\mathrm{r})$ & 0.9974 & 0.1551 \\
\hline LOQ & & 0.9959 \\
Nominal Concentration $\left(\mu \mathrm{g} \mathrm{mL}^{-1}\right)$ & 0.20 & 0.20 \\
Analyzed Concentration $\left(\mu \mathrm{g} \mathrm{mL} \mathrm{mL}^{-1}\right)$ & 0.20 & 0.20 \\
CV $(\%)^{\mathrm{a}}$ & 10.3 & 0.20 \\
E $(\%)^{\mathrm{b}}$ & 0.3 & 3.3 \\
\hline
\end{tabular}

${ }^{\mathrm{a}} \mathrm{CV}$, expressed as coefficient of variation in percentage $(\%)$; ${ }^{\mathrm{b}} \mathrm{E}$, expressed as relative error in percentage $(\%)$.

Table 3. Precision and accuracy of the method for the analysis of 5-hydroxyomeprazole, omeprazole and omeprazole sulphone in Czapek Dox medium

\begin{tabular}{|c|c|c|c|c|c|c|c|c|c|}
\hline \multirow{2}{*}{$\begin{array}{l}\text { Drug } \\
\text { Nominal concentration }(\mu \mathrm{g} \mathrm{mL}-1)\end{array}$} & \multicolumn{3}{|c|}{ 5-Hydroxyomeprazole } & \multicolumn{3}{|c|}{ Omeprazole } & \multicolumn{3}{|c|}{ Omeprazole Sulfone } \\
\hline & 1.00 & 3.00 & 6.00 & 1.00 & 3.00 & 6.00 & 1.00 & 3.00 & 6.00 \\
\hline \multicolumn{10}{|l|}{ Intra-day $(n=6)$} \\
\hline Analyzed concentration $\left(\mu \mathrm{g} \mathrm{mL} L^{-1}\right)$ & 0.94 & 2.70 & 5.46 & 0.92 & 2.88 & 5.29 & 0.88 & 3.05 & 5.50 \\
\hline Precision $(\mathrm{CV}, \%)^{\mathrm{a}}$ & 5.3 & 7.9 & 4.2 & 4.0 & 12.8 & 9.9 & 3.9 & 9.0 & 6.1 \\
\hline Accuracy $(\mathrm{E}, \%)^{\mathrm{b}}$ & -6.4 & -10.1 & -9.0 & -8.1 & -3.9 & -11.9 & -12.5 & 1.8 & -8.3 \\
\hline \multicolumn{10}{|l|}{ Inter-day $(n=3)$} \\
\hline Analyzed concentration $\left(\mu \mathrm{g} \mathrm{mL} \mathrm{L}^{-1}\right)$ & 0.89 & 2.73 & 5.37 & 0.92 & 2.77 & 5.21 & 0.87 & 2.96 & 5.30 \\
\hline Precision $(\mathrm{CV}, \%)^{\mathrm{a}}$ & 6.5 & 7.7 & 6.4 & 5.5 & 14.4 & 7.1 & 9.4 & 6.3 & 7.8 \\
\hline Accuracy $(\mathrm{E}, \%)^{\mathrm{b}}$ & -10.6 & -9.0 & -10.5 & -7.8 & -7.6 & -13.2 & -12.7 & -1.3 & -11.7 \\
\hline
\end{tabular}

${ }^{\mathrm{a}} \mathrm{CV}$, expressed as coefficient of variation in percentage $(\%)$; ${ }^{\mathrm{b}} \mathrm{E}$, expressed as relative error in percentage $(\%)$; ${ }^{\mathrm{n}}=$ number of determinations: 6 for intraday assay and 3 for inter-day assay.

Table 4. Stability test of 5-hydroxyomeprazole, omeprazole and omeprazole sulphone in Czapek Dox medium

\begin{tabular}{|c|c|c|c|c|c|c|c|c|c|}
\hline \multirow[t]{2}{*}{ Drug } & \multicolumn{3}{|c|}{ 5-Hydroxyomeprazole } & \multicolumn{3}{|c|}{ Omeprazole } & \multicolumn{3}{|c|}{ Omeprazole Sulfone } \\
\hline & $p$-value ${ }^{\mathrm{b}}$ & $\mathrm{CV}(\%)^{\mathrm{c}}$ & $\mathrm{E}(\%)^{\mathrm{d}}$ & $p$-value ${ }^{\mathrm{b}}$ & $\mathrm{CV}(\%)^{\mathrm{c}}$ & $\mathrm{E}(\%)^{\mathrm{d}}$ & $p$-value ${ }^{\mathrm{b}}$ & $\mathrm{CV}(\%)^{\mathrm{c}}$ & $\mathrm{E}(\%)^{\mathrm{d}}$ \\
\hline \multicolumn{10}{|c|}{$8 \mathrm{~h}$ auto sampler $(n=6)^{\text {a }}$} \\
\hline $1 \mu \mathrm{g} \mathrm{mL}{ }^{-1}$ & 0.72 & 5.9 & 1.3 & 0.92 & 5.7 & -0.3 & 0.81 & 4.1 & 0.5 \\
\hline $6 \mu \mathrm{g} \mathrm{mL}^{-1}$ & 0.74 & 3.8 & -0.9 & 0.81 & 5.1 & 0.8 & 0.67 & 2.4 & 1.2 \\
\hline \multicolumn{10}{|c|}{ Freeze-thaw cycles $(n=6)^{\mathrm{a}}$} \\
\hline $1 \mu \mathrm{g} \mathrm{mL} L^{-1}$ & 0.70 & 4.9 & 1.3 & 0.73 & 1.9 & 0.9 & 0.99 & 5.8 & -0.1 \\
\hline $6 \mu \mathrm{g} \mathrm{mL}^{-1}$ & 0.90 & 7.3 & -0.5 & 0.99 & 7.3 & -0.1 & 0.69 & 5.3 & -1.4 \\
\hline \multicolumn{10}{|c|}{$48 \mathrm{~h}$ freeze $(n=6)^{\mathrm{a}}$} \\
\hline $1 \mu \mathrm{g} \mathrm{mL} L^{-1}$ & 0.99 & 8.9 & 0.1 & 0.86 & 7.2 & 0.7 & 0.81 & 6.6 & 0.7 \\
\hline $6 \mu \mathrm{g} \mathrm{mL}^{-1}$ & 0.93 & 7.2 & 0.3 & 0.93 & 4.1 & 0.2 & 0.66 & 3.4 & 1.3 \\
\hline
\end{tabular}

${ }^{\mathrm{a}} n=$ number of determinations; ${ }^{\mathrm{b}}$ Level of significance set at $p \leq 0.05$; ${ }^{\mathrm{c}} \mathrm{CV}$, expressed as coefficient of variation in percentage (\%); ${ }^{\mathrm{d}} \mathrm{E}$, expressed as relative error in percentage $(\%)$.

\section{Application of method in the biotransformation study of $O M Z$ by endophytic and phytopathogenic fungi}

The biotransformation of OMZ by Cunninghamella elegans ATCC 9245 was previously studied. ${ }^{54}$ These authors reported that the predominant pathway involved in this biotransformation was the reduction of the sulphoxide group to sulfide and the hydroxylation of the molecule's aromatic rings and side chain.
The biotransformation reactions of OMZ that were monitored in this work involves the aliphatic hydroxylation of the methyl group of the aromatic ring yielding the formation of the metabolite 5-HOMZ and the sulfonation (in the sulfur atom) resulting the metabolite OMZ SUL. Table 5 presents the obtained data.

The fungus Colletotrichum acutatum (CA) biotransformed $9.6 \%$ of OMZ to OMZ SUL in $24 \mathrm{~h}$ of incubation. In addition, Botrytis cinerea (BC) was the 


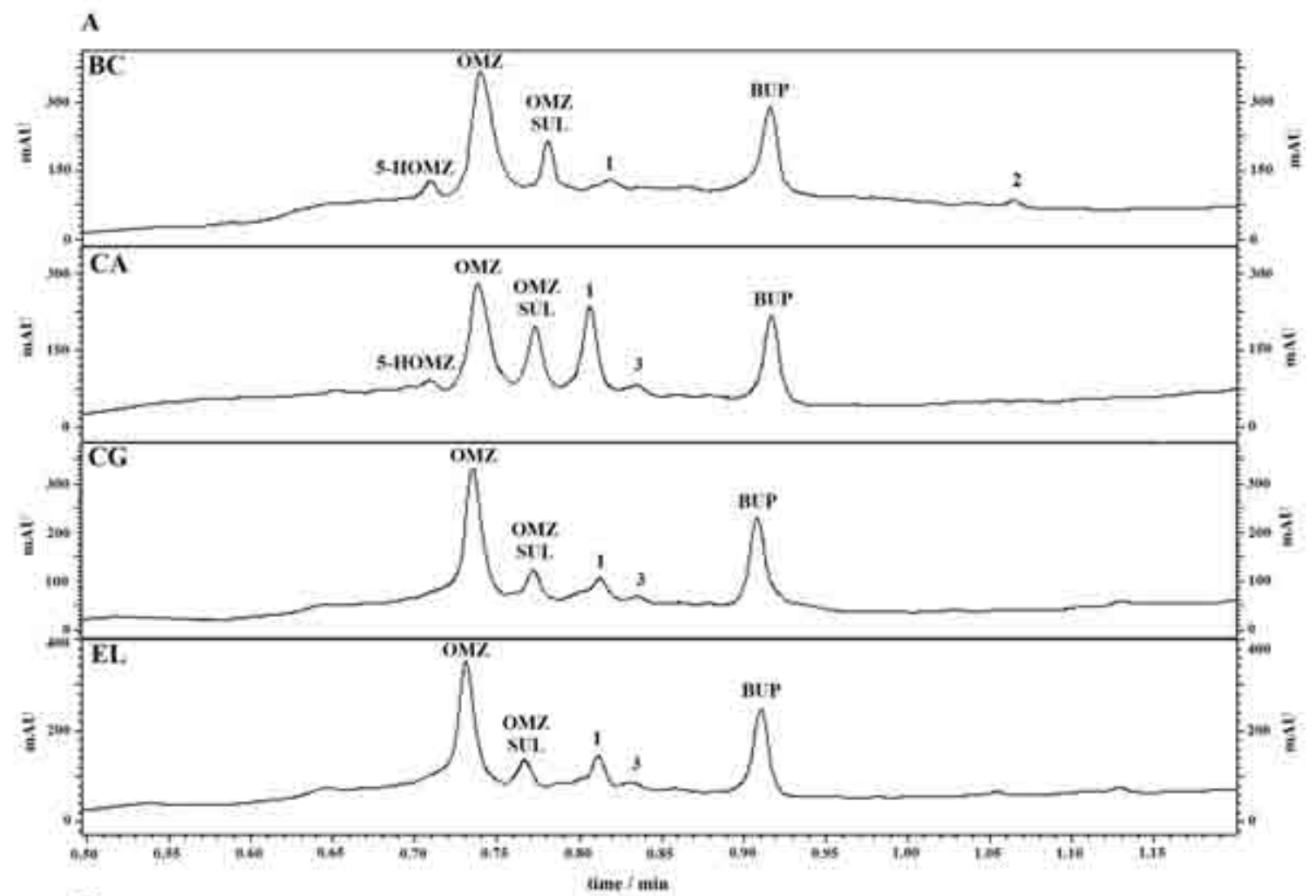

B

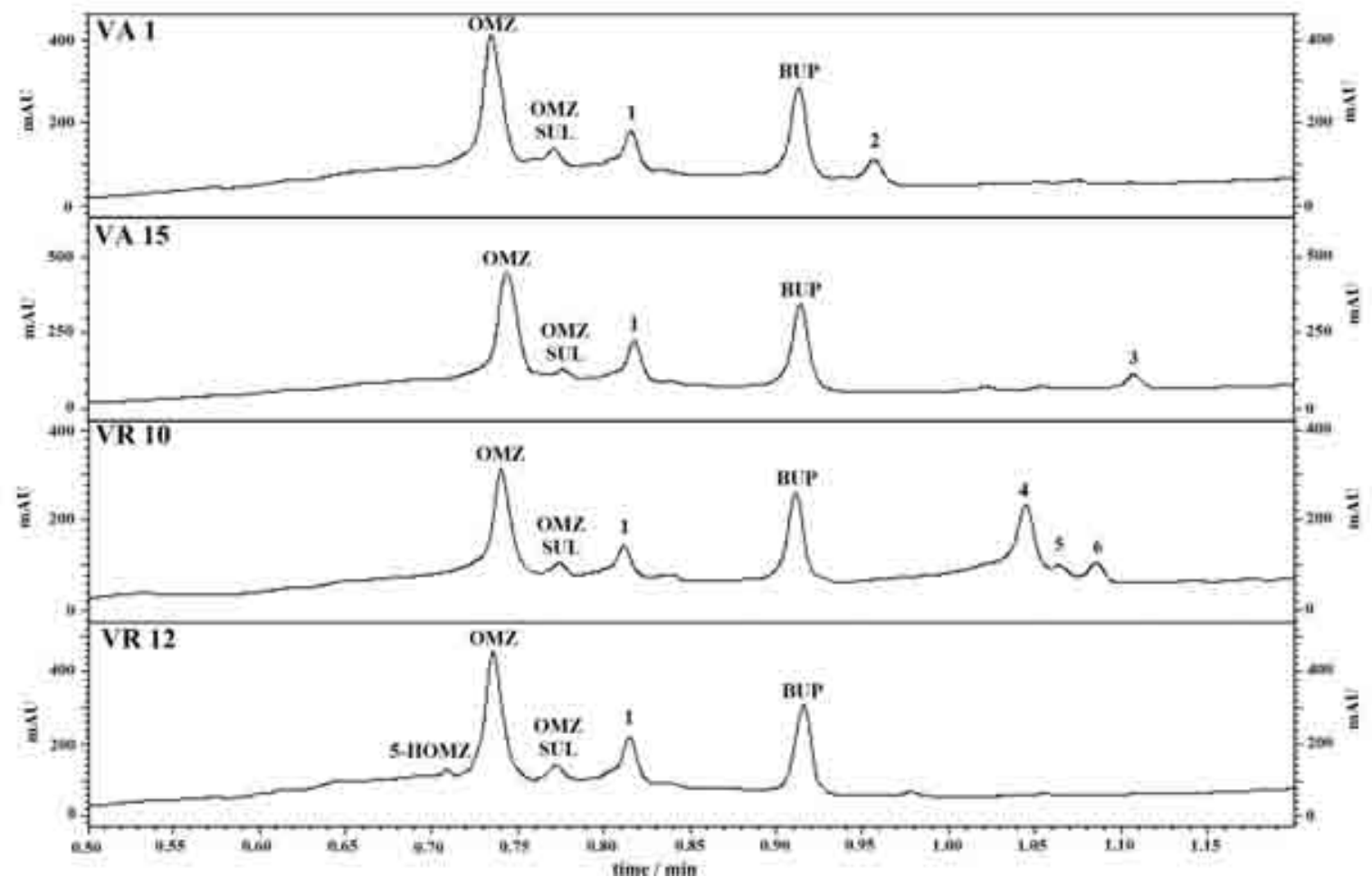

Figure 4. A) Chromatograms referring to the analysis of biotransformation process employing the phytopatogenic fungi: Botrytis cinerea (BC, 1 and 2: unknown biotransformation products), Colletotrichum acutatum (CA, 1 and 3: unknown biotransformation products), Colletotrichum gloeosporioides (CG, 1 and 3: unknown biotransformation products) and Eutypa lata (EL, 1 and 3: unknown biotransformation products); B) Chromatograms referring to the analysis of biotransformation process the endophytic fungi: Glomerella cingulata (VA1, 1: unknown biotransformation product and 2: unknown secondary metabolite), Guignardia mangiferae (VA15, 1: unknown biotransformation product and 3: unknown secondary metabolite), Chaetomium globosum (VR10, 1: unknown biotransformation product, 4, 5 and 6: unknown secondary metabolites) and Aspergillus fumigatus (VR12, 1: unknown biotransformation product). The conditions are the same as in Figure 2. 
Table 5. Biotransformation of omeprazole to 5-hydroxyomeprazole and/or omeprazole sulphone

\begin{tabular}{|c|c|c|c|c|}
\hline \multirow[t]{2}{*}{ Fungi } & \multirow{2}{*}{$\frac{\text { Initial concentration }\left(\mu \mathrm{g} \mathrm{mL} \mathrm{m}^{-1}\right)}{\text { Omeprazole }}$} & \multicolumn{3}{|c|}{ Obtained concentration $\left(\mu \mathrm{g} \mathrm{mL}^{-1}\right)$ after $24 \mathrm{~h}$ incubation } \\
\hline & & Omeprazole $^{\mathrm{a}}$ & 5-Hydroxyomeprazole & Omeprazole Sulphone \\
\hline \multicolumn{5}{|l|}{ Phytopathogenic fungi ${ }^{b}$} \\
\hline Botrytis cinerea $(\mathrm{BC})$ & $9.34(100 \%)$ & $6.23(66.8 \%)$ & $0.20(2.1 \%)$ & $0.68(7.3 \%)$ \\
\hline Colletotrichum acutatum (CA) & $9.52(100 \%)$ & $5.05(54.7 \%)$ & $<$ LOQ & $0.91(9.6 \%)$ \\
\hline Colletotrichum gloeosporioides (CG) & $9.33(100 \%)$ & $7.59(81.3 \%)$ & $\mathrm{ND}^{\mathrm{c}}$ & $0.62(6.6 \%)$ \\
\hline Eutypa lata (EL) & $9.21(100 \%)$ & $7.05(74.1 \%)$ & $\mathrm{ND}^{\mathrm{c}}$ & $0.53(5.8 \%)$ \\
\hline \multicolumn{5}{|l|}{ Endophytic fungi $^{\mathrm{b}}$} \\
\hline Glomerella cingulata (VA1) & $9.27(100 \%)$ & $6.59(71.1 \%)$ & $\mathrm{ND}^{\mathrm{c}}$ & $<$ LOQ \\
\hline Guignardia mangiferae (VA15) & $9.65(100 \%)$ & $6.49(67.3 \%)$ & $\mathrm{ND}^{\mathrm{c}}$ & $<\mathrm{LOQ}$ \\
\hline Chaetomium globosum (VR10) & $9.56(100 \%)$ & $5.00(52.4 \%)$ & NDc & $<$ LOQ \\
\hline Aspergillus fumigatus (VR12) & $9.14(100 \%)$ & $7.61(83.3 \%)$ & $<$ LOQ & $0.40(4.3 \%)$ \\
\hline
\end{tabular}

${ }^{\mathrm{a}}$ Analysis in duplicate $(n=2)$; ${ }^{\mathrm{b}}$ The control flasks did not present formation of the omeprazole metabolites; ${ }^{\mathrm{c} N D}$ : non-detected.

only fungus that biotransformed OMZ to 5-HOMZ (2.1\%). Figure 4 shows the chromatograms of all phytopathogenic fungi (Figure 4a) and endophytic fungi (Figure 4b) studied after $24 \mathrm{~h}$ of incubation. The spectra of all target peaks were compared with the standard and purity peaks were calculated and presented values higher than 0.99. As informed before, longer incubation times were not evaluated due to $\mathrm{OMZ}$ decomposition.

In general, the phytopathogenic fungi studied were more efficient to biotransform OMZ, and the four fungi studied were able to form the metabolite OMZ SUL. The sulfonation reaction was more prevalent for all studied fungi. The difference in biotransformation process could be attributed to the different enzymes present in the studied strains. Therefore, the production of a specific metabolite OMZ could be assigned by selecting the appropriate fungus.

\section{Conclusions}

The method developed in this study employing fast liquid chromatography for the simultaneous resolution of OMZ, 5-HOMZ and OMZ SUL was performed in a short period of time $(<2.0 \mathrm{~min})$, allowing the analysis of large number of samples with low use of organic solvents. The method validated presented all parameters in accordance with the confidence criteria established in the literature. The method was successfully applied to study the biotransformation of OMZ by fungi. The phytopathogenic fungi studied were more efficient to biotransform OMZ, and OMZ SUL was the main metabolite obtained.

\section{Acknowledgments}

The authors are grateful to Fundação de Amparo à Pesquisa do Estado de São Paulo (FAPESP), Conselho
Nacional de Desenvolvimento Científico e Tecnológico (CNPq), and to Coordenação de Aperfeiçoamento de Pessoal de Nível Superior (CAPES) for financial support and for granting research fellowships. Financial support from Junta Andalucía Project P07-FQM-02689 is also gratefully acknowledged.

\section{References}

1. Rang, H. P.; Dale, M. M.; Ritter, J. M.; Moore, P. K.; Farmacologia, 4a. ed., Guanabara Koogan: Rio de Janeiro, Brasil, 2001.

2. Clarke's; Analysis of Drug and Poisons, Pharmaceutical Press, Cd-Rom version: London, 2004.

3. Farinha, A.; Bica, A.; Pais, J. P.; Toscano, M. C.; Tavares, P.; Eur. J. Pharm. Sci. 1999, 7, 311.

4. Streetmann,D. S.; Bertino, J. S.; Nafziger,A. N.; Pharmacogenetics 2000, 10, 187.

5. Bosch, M. E.; Sánchez, A. J. R.; Rojas, F. S.; Ojeda, C. B.; J. Pharm. Biomed. Anal. 2007, 44, 831.

6. Linden, R.; Ziulkoski, A. L.; Wingert, M.; Tonelloa, P.; Souto, A. A.; J. Braz. Chem. Soc. 2007, 18, 733.

7. Martens-Lobenhoffer, J.; Reiche, I.; Tröger, U.; Mönkemüller, K.; Malfertheiner, P.; Bode-Böger, S. M.; J. Chromatogr. B 2007, 857, 307.

8. Podilsky, G.; Berger-Gryllaki, M.; Testa, B.; Pannatier, A.; J. Liq. Chromatogr. Rel. Technol. 2008, 31, 878.

9. Iuga, C.; Moldovan, M.; Popa, A.; Leucuta, S. E.; Farmacia 2008, 56, 254.

10. Rambla-Alegre, M.; Esteve-Romero, J.; Carda-Broch, S.; Anal. Chim. Acta 2009, 633, 250.

11. Vittal, S.; Ganneboina, R.; Layek, B.; Trivedi, R. K.; Hotha, K. K.; Bharathi, D. V.; Mullangi, R.; Biomed. Chromatogr. 2009, 23, 390.

12. Li, Z.; Yao, J.; Zhang, Z.; Zhang, L.; J. Chromagr Sci. 2009 , 47,881 . 
13. Zhang, W.; Han, F.; Guo, P.; Zhao, H.; Lin, Z. J.; Huang, M.-Q.; Bertelsen, K.; Weng, N.; J. Chromatogr. B 2010, 878, 1169.

14. Borges, K. B.; Sánchez, A. J. M.; Pupo, M. T.; Bonato, P. S.; Collado, I. G.; J. AOAC Int. 2010, 93, 1811.

15. Azerad, R.; Adv. Biochem. Eng. Biot. 1999, 63, 169.

16. Smith, R. V.; Rosazza, J. P.; Arch. Biochem. Biophys. 1974, 161, 551.

17. Smith, R. V.; Rosazza, J. P.; J. Pharm. Sci. 1975, 11, 1737.

18. Clark, A. M.; Hufford, C. D.; Med. Res. Rev. 1991, 11, 473.

19. Abourashed, E. A.; Clark, A. M.; Hufford, C. D.; Curr. Med. Chem. 1999, 6, 359.

20. Pupo, M. T.; Borges, K. B.; Borges, W. S.; Bonato, P. S. In Microbial Biotechnology; Saikai, R.; Bezbaruah, R. L.; Bora, T. Ch., eds.; New India Publishing Agency: New Delhi, India, 2008, ch. 3.

21. Borges, K. B.; Borges, W. S.; Durán-Patrón, R.; Pupo, M. T.; Bonato, P. S.; Collado, I. G.; Tetrahedron: Asymm. 2009, 20, 385.

22. Wilson, D.; Oikos 1995, 73, 274.

23. Schulz, B.; Boyle, C.; Mycol. Res. 2005, 109, 661.

24. Borges, K. B.; Borges, W. S.; Pupo, M. T.; Bonato, P. S.; Appl. Microbiol. Biotechnol. 2007, 77, 669.

25. Borges, K. B.; Borges, W. S.; Pupo, M. T.; Bonato, P. S.; J. Pharm. Biomed. Anal. 2008, 46, 945.

26. Borges, K. B.; Pupo, M. T.; Bonato, P. S.; Electrophoresis 2009 , 30, 3910.

27. Borges, K. B.; Okano, L. T.; Pupo, M. T.; Bonato, P. S.; Chromatographia 2009, 70, 1335.

28. Borges, W. S.; Borges, K. B.; Bonato, P. S.; Said, S.; Pupo, M. T.; Curr. Org. Chem. 2009, 13, 1137.

29. Barth, T.; Pupo, M. T.; Borges, K. B.; Okano, L. T.; Bonato, P. S.; Electrophoresis 2010, 31, 1521.

30. Stanosz, G. R.; Smith, D. R.; Guthmiller, M. A.; Stanosz, J. C.; Mycologia 1997, 89, 525.

31. Daoubi, M.; Hernández-Galán, R.; Benharref, A.; Collado, I. G.; J. Agric. Food Chem. 2005, 53, 6673.

32. Bustillo, A. J.; García-Pajón, C. M.; Aleu, J.; Hernández-Galán, R.; Collado, I. G.; Tetrahedron: Asymm. 2003, 14, 3755.

33. Guidance for industry, Bioanalytical Method Validation, Center for Drug Evaluation and Research, United States Food and Drug Administration, http://www.fda.gov/eder/guidance/index.htm accessed in May 2009.

34. Mazzeo, J. R.; Neue, U. D.; Kele, M.; Plumb, R. S.; Anal. Chem. 2005, 77, 460A.
35. Swartz, M. E.; LCGC North Am. Suppl. S 2005, Suppl. S, 8.

36. Nguyen, D. T. T.; Guillarme, D.; Rudaz, S.; Veuthey, J. L.; J. Sep. Sci. 2006, 29, 1836.

37. Nguyen, D. T. T.; Guillarme, D.; Rudaz, S.; Veuthey, J. L.; J. Chromatogr. A 2006, 1128, 105.

38. Guillarme, D.; Nguyen, D. T. T.; Rudaz, S.; Veuthey, J. L.; Eur. J. Pharm. Biopharm. 2007, 66, 475.

39. Guillarme, D.; Nguyen, D. T. T.; Rudaz, S.; Veuthey, J. L.; Eur. J. Pharm. Biopharm. 2008, 68, 430.

40. Yan, B.; Zhao, J.; Brown, J. S.; Blackwell, J.; Carr, P. W.; Anal. Chem. 2000, 72, 1253.

41. Dolan, J. W.; J. Chromatogr. A 2002, 965, 195.

42. Clark, J.; Pharm. Technol. Europe 2004, 16, 41.

43. Guillarme, D.; Heinisch, S.; Rocca, J. L.; J. Chromatogr. A 2004, 1052, 39.

44. Yang, X.; Ma, L.; Carr, P. W.; J. Chromatogr. A 2005, 1079, 213.

45. Barrioulet, M. P.; Heinisch, S.; Rocca, J. L.; Spectra Anal. 2007, 36,38 .

46. Guillarme, D.; Russo, R.; Rudaz, S.; Bicchi, C.; Veuthey, J. L.; Curr. Pharm. Anal. 2007, 4, 221.

47. Nakanishi, K.; Soga, N.; J. Am. Ceram. 1991, 74, 2518.

48. Nakanishi, K.; Soga, N.; J. Non-Cryst. Solids 1992, 139, 1.

49. Nakanishi, K.; J. Porous Mat. 1997, 4, 67.

50. Motokawa, M.; Kobayashi, H.; Ishizuka, N.; Minakuchi, H.; Nakanishi, K.; Jinnai, H.; Hosoya, K.; Ikegami, T.; Tanaka, N.; J. Chromatogr. A 2002, 961, 53.

51. Minakuchi, H.; Nakanishi, K.; Soga, N.; Ishizuka, N.; Tanaka, N.; J. Chromatogr. A 1997, 762, 135.

52. Cabrera, K.; Wieland, G.; Lubda, D.; Nakanishi, K.; Soga, N.; Minakuchi, H.; Unger, K. K.; TrAC-Trend Anal. Chem. 1998, 17,50 .

53. Wallmark, B.; Lindberg, P.; ISI Atlas of Science-Pharmacology 1987, 1,158 .

54. Pearce, C. M.; Lushnikova, M. V.; J. Mol. Catal. B-Enzym. 2006, $41,87$.

Submitted: August 11, 2010 Published online: February 22, 2011

FAPESP has sponsored the publication of this article. 